\section{Efektivitas Model Project Based Learning (Pjbl) Terhadap Hasil Belajar Biologi Peserta Didik Kelas X SMA Negeri 4 Pinrang Materi Perubahan Lingkungan dan Upaya Mengatasinya}

\author{
Fatmah Kamaruddin \\ Halifah Pagarra \\ Nurhayati B
}

\begin{abstract}
Abstrak. Penelitian ini bertujuan untuk mengetahui pengaruh model pembelajaran Project Based Learning terhadap hasil belajar siswa pada materi perubahan lingkungan kelas X SMA Negeri 4 Pinrang. Jenis penelitian ini adalah penelitian eksperimen semu (Quasy Experimental). Sampel penelitian ini adalah peserta didik kelas X MIA SMA Negeri 4 pinrang yang dipilih dengan cara purposive sampling. Pada kelas X MIA 3 sebagai kelas eksperimen yang diberikan perlakuan dengan dibelajarkan dengan menggunakan model pembelajaran PjBL, sedangkan pada kelas XI MIA II sebagai kelas kontrol dibelajarkan dengan menggunakan model pembelajaran langsung. Teknik pengumpulan data yang digunakan yaitu dalam bentuk pilihan ganda (multiple choice) sebanyak 25 butir soal. Data yang terkumpul dianalisis secara statistik deskriptif dan statistik inferensial. Hasil penelitian menunjukkan peserta didik yang diajar dengan model pembelajaran Project Based Learning (PjBL) memiliki skor rata-rata 73,0 pada kategori sangat baik. Sedangkan hasil belajar peserta didik yang diajar dengan model pembelajaran langsung memiliki skor rata-rata 71,29 berada pada kategori baik dan terdapat pengaruh model pembelajaran Project Based Learning (PJBL) terhadap hasil belajar peserta didik pada materi perubahan lingkungan di SMA Negeri 4 Pinrang.

Kata Kunci: model pembelajaran, Project Based Learning (PjBL), hasil belajar.
\end{abstract}

\section{Pendahuluan}

Pendidikan sebagai salah satu dasar pembentukan karakter generasi penerus bangsa perlu terus dikembangkan dan disesuaikan dengan perkembangan zaman, khususnya untuk memenuhi perkembangan teknologi, olehnya itu sistem pendidikan yang diterapkan di sekolah haruslah mampu membangkitkan kemampuan dan keterampilan peserta didik. Wijayanto dkk (2017) menganggap pendidikan sebagai sektor penting yang mempengaruhi suatu bangsa sehingga dapat dijadikan sebagai sarana untuk memperbaiki kualitas bangsa tersebut. Di Indonesia sendiri, kurikulum sebagai acuan dasar pendidikan nasional telah berulang kali mengalami perubahan dan penyempurnaan. Kurikulum terbaru, yakni kurikulum 2013 merupakan upaya perbaikan kekurangan kurikulum sebelumnya. Anwar (2014) mengungkapkan bahwa fokus utama kurikulum 2013 adalah untuk meningkatkan kemampuan siswa dalam melakukan observasi, bertanya, dan mengomunikasikan pengetahuan yang didapatkannya di sekolah. Semua hal tersebut merupakan kemampuan dasar yang dibutuhkan peserta

\section{Biology Teaching and Learning}

p-ISSN 2621 - 5527

e-ISSN 2621 - 5535

Abstract. This study aims to determine the effect of the Project Based Learning model on student learning outcomes on environmental change material for class $X$ SMA Negeri 4 Pinrang. This type of research is quasi-experimental research (Quasy Experimental). The sample of this study were students of class X MIA SMA Negeri 4 Pinrang who were selected by random sampling. In class X MIA 3 as an experimental class that is given treatment by learning using the PjBL learning model, while in class XI MIA II as a control class is taught using a direct learning model. The data collection technique used is in the form of multiple choice (multiple choice) as many as 25 items. The collected data were analyzed using descriptive statistics and inferential statistics. The results showed that students who were taught with the Project Based Learning (PjBL) learning model had an average score of 73.0 in the very good category. Meanwhile, the learning outcomes of students who were taught with the direct learning model had an average score of 71.29 in the good category and there was an influence of the Project Based Learning (PjBL) learning model on student learning outcomes on environmental change material at SMA Negeri 4 Pinrang.

Keyword: learning models, Project Based Learning (PjBL), learning outcome

Fatmah Kamaruddin Universitas Negeri Makassar Indonesia

Halifah Pagarra Universitas Negeri Makassar Indonesia

Nurhayati B Universitas Negeri Makassar Indonesia 
didik untuk menghadapi masa mendatang. Kurikulum terdahulu dianggap kurang sesuai untuk memaksimalkan perkembangan potensi yang dimiliki peserta didik sebab pembelajaran yang berlangsung lebih berpusat pada guru (teacher oriented). Usaha untuk memaksimalkan potensi dan kemampuan peserta didik perlu melibatkan peran dari peserta didik itu sendiri. Hal inilah yang kemudian menjadi dasar pengembangan kurikulum 2013 yang lebih fokus untuk menambah aktivitas siswa dalam pembelajaran (student oriented) Salah satu sekolah yang telah menerapkan kurikulum 2013 adalah SMA Negeri 4 Pinrang. Kurikulum 2013 mulai diterapkan sekolah ini guna meningkatkan kualitas dan kecakapan peserta didiknya. Berdasarkan hasil observasi yang telah dilakukan, meski telah menerapkan kurikulum 2013, proses pembelajaran tidak serta merta menjadi ideal seperti yang diharapkan. Proses pembelajara yang terjadi di kelas menunjukkan rendahnya keaktifan peserta didik, hal ini dipengaruhi oleh model pembelajaran yang diterapkan oleh guru masih didominasi metode ceramah.

Upaya melibatkan siswa dalam proses pembelajaran dapat dilakukan dengan menerapkan model-model tertentu. Afandi dkk (2013) menyebutkan bahwa model pembelajaran adalah seperangkat prosedur atau pola yang digunakan untuk mencapai tujuan pembelajaran, yang terdiri atas strategi, teknik, metode, bahan, media dan alat pembelajaran. Pedoman dalam melaksanakan pembelajaran, yang terdiri atas langkah-langkah yang telah tersusun dan teruji disebut sebagai model pembelajaran.

Model pembelajaran yang diterapkan dalam suatu proses pembelajaran dapat disesuaikan dengan kebutuhan kelas sehingga pembelajaran berlangsung secara efektif dan efisien (Nurdyansyah dan Eni, 2016). Beberapa model yang telah menjadi budaya dalam pembelajaran yang selama ini dilakukan guru memang kurang melibatkan siswa sehingga model-model pembelajaran baru mulai gencar disuarakan seiring dengan penerapan kurikulum 2013. Model tersebut antara lain Discovery learning, Problem Based Learning (PBL), Discovery Learning, Inquiry dan Project Based Learning (PjBL) (Utami dkk, 2015).

Project Based Learnig (PjBL) merupakan salah satu model yang menuntut siswa untuk terlibat aktif dalam pembelajaran. Hal ini sangat sesuai untuk menjawab kebutuhan di SMA Negeri 4 Pinrang dimana keaktifan peserta didik masih rendah. Hal ini disebabkan, model pembelajaran yang bervariasi jarang digunakan, guru cenderung menggunakan pembelajaran konvensional yaitu menyampaikan informasi kepada siswa dengan ceramah di depan kelas, yang menyebabkan siswa pasif, aktivitas siswa masih tergolong rendah, dimana saat proses belajar mengajar berlangsung, sedikit sekali siswa yang bertanya maupun mengemukakan pendapat. Pembelajaran konvensional ini cendrung monoton, dan bersifat satu arah. Dengan pembelajaran yang monoton dan siswa yang pasif menyebabkan tidak berkembangnya sikap ilmiah siswa, karena siswa hanya bertugas menjadi pendengar dan bertanya apabila diminta guru untuk bertanya. Hal ini sesuai dengan Insyasiska (2015) yang mengemukakan bahwa kurangnya keterlibatan siswa secara total dalam pembelajaran dikarenakan siswa kurang berusaha dalam menemukan informasi sendiri, dan hal ini mengurangi makna dari pembelajaran aktif dan efektif. Para siswa cenderung belajar untuk dapat menjawab soal-soal ulangan dengan menghafal materi pelajaran bukan memahami, menganalisis suatu permasalahan, dan memecahkan masalah yang mungkin dihadapi sehari-hari, sehingga cara berpikir kritisnya kurang terlatih, terbukti pada rata-rata perolehan nilai hasil belajar yang masih kurang.

Nurdyansyah dan Eni (2016) menjelaskan bahwa pendekatan scientific menempatkan peserta didik sebagai subjek yang harus terlibat langsung dalam membangun pengetahuannya dengan bekerja sendiri untuk memecahkan masalah, mewujudkan ide-ide yang dimilikinya serta berusaha memenuhi segala kebutuhannya. Model Project Based Learning (PjBL) dimulai dengan menghadapkan siswa pada masalah untuk dikaji sehingga materi yang dianggap cocok untuk dibelajarkan dengan model ini adalah materi perubahan lingkungan. Isu lingkungan memiliki banyak sekali masalah yang dapat dikaji oleh siswa sebagai dasar dalam pembuatan proyek Nawawi (2017). Hal senada diungkapkan oleh Mayasari dkk (2016) menegaskan bahwa penerapan model Project Based Learning (PjBL) sejatinya mengangkat permasalahanyang 
Efektivitas Model Project Based Learning (Pjbl) Terhadap Hasil

Belajar Biologi Peserta Didik Kelas X SMA Negeri 4 Pinrang

p-ISSN 2621-5527

Materi Perubahan Lingkungan dan Upaya Mengatasinya

e-ISSN 2621-5535

(hlm. 110-118)

bersinggungan dengan kehidupan sehari-hari peserta didik.

Model pembelajaran Project based learning secara umum dapat membuat siswa mengalami proses pembelajaran yang bermakna, siswa membangun pengetahuannya di dalam konteks pengalamannya sendiri, dan dengan pengalaman belajar secara langsung, dapat mendukung untuk mengembangkan keterampilan (Wena, 2009). Model Project based learning secara umum dapat membuat siswa mengalami proses pembelajaran yang bermakna,siswa membangun pengetahuannya di dalam konteks pengalamannya sendiri, dan dengan pengalaman belajar secara langsung, dapat mendukung untuk mengembangkan keterampilan.

Pada penelitian yang relevan telah dilakukan oleh Mahanal dan Darmawan (2009) menyimpulkan bahwa siswa yang diajar dengan model Project Based Learning pada mata pelajaran biologi memiliki sikap dan pemahaman konsep yang lebih tinggi 11,65\% dan 81,05\% daripada siswa yang diajar dengan pembelajaran konvensional. Rata-rata penilaian sikap siswa kelas eksperimen sebesar 89.490 dan kelas kontrol sebesar 80.151, maka mendapati hasil keterampilan proses sains lebih baik daripada pembelajaran dengan menggunakan model pembelajaran konvensional. Penelitian yang dilakukan Wijayanto dkk (2017) menunjukkan bahwa penerapan model Project Based Learning (PjBL) dalam pembelajaran mampu meningkatkan hasil belajar siswa, khususnya dalam ranah kognitif dengan presentase $56,62 \%$ meningkat ke $82,60 \%$.

Disamping itu, penelitian lain telah dilakukan oleh Insyasiska (2015) menunjukkan adanya peningkatan kemampuan kognitif, rata-rata skor kemampuan kognitif siswa yang diajar dengan pembelajaran berbasis proyek adalah 83,65. Sedangkan rata-rata skor kemampuan kognitif siswa yang diajar dengan pembelajaran secara konvensional adalah 70,13. Kelas eksperimen memiliki kemampuan kognitif 28,9\% lebih tinggi daripada kelas kontrol. Hal ini senada dengan hasil penelitian yang disampaikan oleh Indriwati (2007) dalam disertasinya bahwa strategi pembelajaran berbasis proyek merupakan strategi yang efektif untuk meningkatkan hasil belajar kognitif tinggi dan kecakapan hidup.

Model pembelajaran berbasis proyek akan membutuhkan keterampilan siswa dalam proses pembelajaran mulai merencanakan proyek hingga terbentuknya suatu produk (proyek), maka akan memenuhi ketercapaian indikator mulai dari peserta didik melakukan keterampilan mengamati (observasi), klasifikasi, interpretasi, prediksi, berkomunikasi, berhipotesis, merencanakan percobaan, menerapkan konsep hingga mengajukkan pertanyaan. Berdasarkan pemaparan di atas maka penulis melakukan penelitian yang berjudul "Efektivitas Model Project Based Learning (PjBL) terhadap Hasil Belajar Biologi Peserta Didik Kelas X SMA Negeri 4 Pinrang Materi Perubahan Lingkungan dan Upaya Mengatasinya".

\section{Metode Penelitian}

Jenis penelitian ini adalah penelitian pre-experimental design. Populasi dalam penelitian ini adalah peserta didik kelas X MIA SMA Negeri 4 Pinrang pada tahun ajaran 2019/2020, yang terdiri dari 3 rombongan belajar. Variabel bebas dalam penelitian ini yaitu model pembelajaran Project based learning. Variabel terikat pada penelitian ini adalah hasil belajar peserta didik.

Sampel penelitian ini adalah rombongan belajar kelas X MIA 1 SMA Negeri 4 Pinrang menggunakan tehnik sampling purposive yaitu tehnik penentuan sampel dengan pertimbangan tertentu. Kelas eksperimen dibelajarkan dengan menggunakan model pembelajaran Project based learning.

Teknik pengumpulan data yang digunakan yaitu dalam bentuk pilihan ganda (multiple choice) sebanyak 25 butir soal. Soal yang diujikan adalah soal yang telah disusun dan dikembangkan oleh peneliti sebagai alat untuk mengumpulkan data hasil belajar terhadap mata pelajaran biologi pada materi perubahan lingkungan dan upaya mengatasinya. Adapun urutan pengumpulan data yang dilakukan sebagai berikut: (1) Melakukan observasi pada sekolah yang akan diteliti, serta menentukan kelas yang akan dijadikan sebagai objek penelitian, (2) Menyusun 
perangkat pembelajaran dan instrumen penelitian, (3) Melakukan tes awal (pre-test) pada kelas eksperimen, (4) Memberikan perlakuan (treatment) pada kelas eksperimen dengan menggunakan model pembelajaran Project Based Learning , (5) Melakukan tes akhir (post-test) pada kelas eksperimen dengan soal yang sama, (6) Menilai hasil tes yang diperoleh untuk dijadikan sebagai laporan penelitian.

\section{Hasil dan Pembahasan}

Penelitian ini dilaksanakan untuk melihat adanya pengaruh model pembelajaran Project Based Learning (PjBL) hasil belajar peserta didik di SMA Negeri 4 Pinrang pada materi Perubahan lingkungan. Pada penelitian ini yang menjadi kelas eksperimen adalah kelas XI MIA 3 sedangkan kelas kontrol adalah Materi yang dibelajarkan adalah materi Perubahan lingkungan.

Tabel 1 Hasil Analisis Statistik

\begin{tabular}{|l|c|c|c|c|}
\hline \multirow{2}{*}{$\begin{array}{c}\text { Statistik } \\
\text { Deskriptif }\end{array}$} & \multicolumn{4}{|c|}{ Nilai Hasil Belajar } \\
\cline { 2 - 5 } & \multicolumn{2}{|c|}{ Kelompok Eksperimen } & \multicolumn{2}{c|}{ Kelompok Kontrol } \\
\hline & Pretes & Posttes & Pretes & Posttes \\
\hline Nilai Terendah & 30 & 67 & 33 & 57 \\
\hline Nilai Tertinggi & 55 & 87 & 54 & 82 \\
\hline Rata-rata & 44,08 & 75,38 & 42,71 & 71,29 \\
\hline Standar Deviasi & 7,401 & 6,755 & 6,362 & 8,259 \\
\hline
\end{tabular}

Tabel 1 data hasil belajar peserta didik untuk kelas kontrol terlihat bahwa skor rata-rata yang diperoleh peserta didik untuk pretest adalah 42,71 dari skor tertinggi 100 dan untuk posttest adalah 71,29 dari skor tertinggi 100. Skor pretest yang dicapai oleh peserta didik tersebar dari skor terendah 33,00 sampai skor tertinggi 54,00. Selanjutnya, skor posttest yang dicapai oleh peserta didik tersebar dari skor terendah 57,00 sampai skor tertinggi 82,00.

Data hasil belajar peserta didik untuk kelas eksperimen, terlihat bahwa skor rata- rata yang diperoleh peserta didik untuk pretest adalah 44,08 dari skor tertinggi 100 dan untuk posttest adalah 75,38 dari skor tertinggi 100. Skor pretest yang dicapai oleh peserta didik tersebar dari skor terendah 30,00 sampai skor tertinggi 55,00. Selanjutnya, skor posttest yang dicapai oleh peserta didik tersebar dari skor terendah 67,00 sampai skor tertinggi 87,00Nilai hasil belajar peserta didik selanjutnya dikelompokkan berdasarkan pengkategorian hasil belajar peserta didik. Distribusi frekuensi dan persentase hasil belajar peserta didik pada kelompok eksperimen dan kelompok kontrol dapat dilihat pada tabel 2 . Berdasarkan keseluruhan nilai hasil belajar yang diperoleh siswa maka dapat dikategorikan seperti pada Tabel 2

Tabel 2 Distribusi Frekuensi dan Persentase Kategori Hasil Belajar

\begin{tabular}{|c|c|c|c|c|c|c|c|c|c|}
\hline \multirow{2}{*}{ Interval } & \multirow{2}{*}{ Kategori } & & \multicolumn{3}{|c|}{ Kelompok Eksperimen } & \multicolumn{5}{c|}{ Kelompok Kontrol } \\
\cline { 3 - 10 } & & & Pretest & & Posttest & & Pretest & & Posttest \\
\hline & & $\mathrm{F}$ & $\%$ & $\mathrm{~F}$ & $\%$ & $\mathrm{~F}$ & $\%$ & $\mathrm{~F}$ & $\%$ \\
\hline $86-100$ & $\begin{array}{c}\text { Sangat } \\
\text { baik }\end{array}$ & 0 & 0 & 3 & 12,5 & 0 & 0 & 0 & 0 \\
\hline $71-85$ & Baik & 0 & 0 & 14 & 58,3 & 0 & 0 & 11 & 45,8 \\
\hline $56-70$ & Cukup & 0 & 0 & 7 & 29,2 & 0 & 0 & 13 & 54,2 \\
\hline $41-55$ & Kurang & 17 & 70,8 & 0 & 0 & 13 & 54,2 & 0 & 0 \\
\hline$\leq 40$ & $\begin{array}{c}\text { Sangat } \\
\text { Kurang }\end{array}$ & 7 & 29,2 & 0 & 0 & 11 & 45,8 & 0 & 0 \\
\hline & Jumlah & 24 & 100 & 24 & 100 & 24 & 100 & 24 & 100 \\
\hline
\end{tabular}


Efektivitas Model Project Based Learning (Pjbl) Terhadap Hasil

Tabel 2 menunjukkan frekuensi dan persentase hasil belajar peserta didik kelompok eksperimen dan kelompok kontrol pada materi perubahan lingkungan.

Berdasarkan tabel di atas, nilai pretest pada kelompok eksperimen yang diajar dengan menerapkan model pembelajaran Project Based Learning 70,8\% berada pada kategori kurang dan $29,2 \%$ berada berada pada kategori sangat kurang, sedangkan pada kelompok kontrol yang diajar dengan menerapkan model pembelajaran konvensional 54,2\% berada pada kategori kurang dan $45,8 \%$ berada pada kategori cukup. Sementara nilai posttest pada kelompok eksperimen 12,5\% berada pada kategori sangat baik, 58,3\% berada pada kategori baik, dan 29,2\% berada pada kategori cukup, sedangkan pada kelompok kontrol $45,8 \%$ berada pada baik dan $54,2 \%$ berada pada kategori cukup.

Data diatas menunjukkan bahwa siswa pada kelas eksperimen yang awalnya memperoleh nilai rendah dengan kategori sangat kurang pada pretest memperoleh nilai yang lebih tinggi dengan kategori baik hingga sangat baik setelah mendapatkan perlakuan berupa dibelajarkan dengan model Project Based Learning (PjBL). Adapun siswa pada kelas kontrol, yang awalnya memperoleh nilai dengan kategori sangat kurang dominan berada pada kategori cukup sedangkan lainnya berada pada kategori baik. Analisis statistik inferensial digunakan untuk menguji hipotesis penelitian dengan menggunakan analisis kovarian (anacova) melalui program aplikasi SPSS for windows release 22.0.

Sebelum dilakukan pengujian hipotesis terlebih dahulu dilakukan uji prasyarat yaitu uji normalitas dan uji homogenitas. Uji normalitas data bertujuan untuk mengetahui apakah data pada dua kelompok sampel berdistribusi normal atau tidak. Uji normalitas data menggunakan uji Kolmogorov-Smirnov, dengan kriteria pengujian yaitu data dikatakan berdistribusi normal jika nilai signifikansi (2-tailed) yang diperoleh $\alpha>0,05$. Sebaliknya, jika nilai signifikansi (2-tailed) $\alpha$ $<0,05$ maka dapat disimpulkan bahwa sampel penelitian tidak berdistribusi normal. Hasil uji normalitas terhadap data minat belajar dapat dilihat pada Tabel 3.

Tabel 3 Hasil Uji Normalitas Hasil Belajar

\begin{tabular}{|c|c|c|c|}
\hline \multicolumn{4}{|c|}{ Uji Normalitas } \\
\hline \multicolumn{2}{|c|}{ Kelompok } & Sig. & Keterangan \\
\hline Pretest & Model Pembelajaran PjBL & .200 & $\begin{array}{l}\text { BerdistribusiN } \\
\text { ormal }\end{array}$ \\
\hline & $\begin{array}{l}\text { Model Pembelajaran Langsung } \\
\text { (Direct Instruction) }\end{array}$ & .193 & $\begin{array}{l}\text { BerdistribusiN } \\
\text { ormal }\end{array}$ \\
\hline Posttest & Model Pembelajaran PjBL & .200 & $\begin{array}{l}\text { BerdistribusiN } \\
\text { ormal }\end{array}$ \\
\hline & $\begin{array}{l}\text { Model Pembelajaran Langsung } \\
\text { (Direct Instruction) }\end{array}$ & .200 & $\begin{array}{l}\text { BerdistribusiN } \\
\text { ormal }\end{array}$ \\
\hline
\end{tabular}

Tabel 3 menunjukkan uji normalitas data hasil belajar peserta didik yang dibelajarkan dengan model Project Based Learning (PJBL) dan model konvensional mengindikasikan bahwa kedua kelas berasal dari populasi yang terdistribusi normal. Uji homogenitas bertujuan untuk mengetahui data dalam penelitian ini memiliki variansi yang sama (homogen) atau tidak. Uji homogenitas menggunakan Levene Statistic dengan kriteria jika signifikansi $<0,05$, maka dikatakan bahwavarian dari dua atau lebih kelompok populasi data adalah tidak sama. Sebaliknya, jika nilai signifikansi $>0,05$, maka dikatakan bahwa varian dari dua atau lebih kelompok populasi data adalah sama. Hasil uji homogenitas terhadap data minat belajar dapat dilihat pada Tabel 4. 
Tabel 4 Hasil Uji Homogenitas

\begin{tabular}{|c|c|}
\hline Levene Statistic & Nilai Signifikansi \\
\hline 1,296 & 0,261 \\
\hline
\end{tabular}

Berdasarkan hasil pengolahan data padaTabel 4 diperoleh signifikansi hasil belajar siswa sebesar $0,261>\alpha 0.05$, sehingga dapat dikatakan bahwa variansi data homogen. Untuk menjawab rumusan masalah dilakukan pengujian hipotesis. Pengujian ini dilakukan untuk mengetahui apakah penerapan model pembelajaran Project Based Learning efektif terhadap hasil belajar materi perubahan lingkungan kelas X SMA Negeri 4 Pinrang. Berdasarkan output uji paired sample t-test diperoleh nilai Sig. (2-tailed) sama dengan 0,000 yang berarti $<0,05$, maka $\mathrm{H} 0$ ditolak dan $\mathrm{H} 1$ diterima. Artinya ada perbedaan yang signifikan antara rata-rata nilai pretes dan posttes sehingga dapat disimpulkan bahwa penerapan model pembelajaran Project

Based Learning cukup efektif dalam meningkatkan hasil belajar siswa kelas X materi perubahan lingkungan SMA Negeri 4 Pinrang. Analisis N-gain digunakan untuk menghitung besar peningkatan hasil belajar. Analisis gain ternormalisasi (N-Gain) dimaksudkan untuk melihat keefektifan pembelajaran berdasarkan selisih nilai pretets dan nilai posttest. Rata-rata nilai N-gain hasil belajar siswa kemudian dikelompokkan berdasarkan kategori N-gain yang ditampilkan pada Tabel 5 .

Tabel 5 Hasil rata-rata N-gain Hasil belajar Peserta didik

\begin{tabular}{|l|l|}
\hline \multicolumn{1}{|c|}{ N-Gain } & Kategori \\
\hline 0,5606 & Sedang \\
\hline $56,06 \%$ & $\begin{array}{l}\text { Cukup } \\
\text { efektif }\end{array}$ \\
\hline
\end{tabular}

Tabel 5 Menunjukkan bahwa nilai rata-rata N-gain hasil belajar peserta didik adalah 0,5606 termasuk pada kategori sedang dan presentasi N-gain $56,06 \%$ berdasarkan kriteria $\mathrm{N}$ gain termasuk dalam kategori cukup efektif dalam meningkatkan hasil belajar. Berdasarkan data tersebut dapat dilihat bahwa penerapan model Project Based Learning (PjBL) mempengaruhi peningkatan nilai siswa. Peserta didik yang dibelajarkan dengan model Project Based Learning (PjBL) yang melibatkan keaktifan peserta didik untuk terlibat dalam proses pembelajaran menjadikan nilai hasil belajar pada kelas eksperimen lebih tinggi.

Hal ini menunjukkan bahwa keaktifan siswa dalam pembelajaran berbanding lurus dengan daya serap siswa terhadap materi. Hal ini dipengaruhi oleh pengalaman belajar yang berbeda. Rombongan belajar yang dibelajarkan melalui model Project Based Learning (PjBL) dimulai dengan menghadapkan pada masalah melalui gambar-gambar kerusakan lingkungan sehingga peserta didik tertarik untuk menggali informasi terkait. Peserta didik kemudian diminta untuk menafsirkan masalah berdasarkan gambar yang ditampilkan, kemudian diminta memberikan solusi berdasarkan masalah yang telah disampaikan. Model PjBL yang diterapkan di kelas eksperimen menitik beratkan pada aktivitas siswa dengan melakukan investigasi yang mendalam tentang suatu masalah dan mencari solusi yang relevan yang diimplementasikan dalam pengerjaan proyek. Siswa melakukan pengerjaan proyek sehingga siswa mengalami proses pembelajaran yang bermakna dengan pengetahuan sendiri.

Siswa diberi kerangka atau rencana penyelesaian kegiatan proyek yang dapat menuntun siswa untuk menemukan solusi masalah tersebut sehingga mampu menyelesaikan proyek sesuai dengan waktu yang ditentukan. Selain rencana penyelesaian kegiatan proyek, siswa juga ditugaskan untuk membuat laporan proyek yang diantaranya berisi tentang langkah kerja proyek dan deskripsi hasil proyek. Hal tersebut dapat mengembangkan pola pikir siswa untuk mengkontruksi pengetahuan baru yang dikaitkan dengan pengetahuan yang sudah ada sesuai 
dengan lingkungan sekitarnya. Adapun materi perubahan lingkungan mengkaji berbagai perubahan di lingkungan sekitar sehingga siswa tertarik mengikuti pembelajaran. Hal ini sesuai dengan penelitian yang dilakukan oleh Utami, dkk (2015) yang menyebutkan bahwa siswa yang dibelajarkan dengan model Project Based Learning (PjBL) pada materi perubahan lingkungan menunjukkan antusiasme yang tinggi untuk terlibat dalam pembelajaran. Hal ini dipicu oleh pokok bahasan yang dekat dengan siswa sehingga siswa tertarik dan aktif dalam setiap diskusi kelompok. Selain itu model PjBL juga dapat meningkatkan keterampilan manajemen, dalam hal ini siswa di kelas eksperimen belajar bertanggung jawab untuk melengkapi tugas-tugas proyek dan belajar bertanggung jawab dalam pemberian instruksi dalam. Proyek yang dibuat siswa dikerjakan secara kolaboratif dengan teman kelompok dengan begitu keterampilan berkomunikasi dan bekerja sama juga dilatih dalam proses pengerjaan proyek, dimana masalahmasalah yang ditemui pada saat pengerjaan proyek dihadapi dan diselesaikan secara bersama. Di samping itu, alokasi waktu yang telah disepakati sebelumnya juga melatih siswa untuk dapat bekerja secara disiplin. Model Project Based Learning (PjBL) dianggap cocok dalam meningkatkan hasil belajar siswa, sebab pada tahapan penentuan pertanyaan mendasar siswa dilatih untuk berpikir lebih luas dalam menilai suatu permasalahan agar dapat menemukan solusi yang tepat untuk mengatasinya.

\section{Kesimpulan}

Berdasarkan hasil penelitian yang dilakukan di SMA Negeri 4 Pinrang dapat disimpulkan bahwa 1) Hasil belajar peserta didik yang diajar dengan model pembelajaran Project Based Learning (PJBL) kategori sangat baik. 2) Model pembelajaran Project Based Learning (PjBL) cukup efektif terhadap hasil belajar siswa pada materi perubahan lingkungan di SMA Negeri 4 Pinrang

\section{Referensi}

Afandi, M, Evi C, \& Oktarina P.W. (2013). Model Dan Metode Pembelajaran Di Sekolah. Unissula Press.

Anwar, R. (2014). Hal-Hal Yang Mendasari Penerapan Kurikulum 2013. Humaniora. 5 (1), 97. Https://Doi.Org/10.21512/Humaniora.V5i1.2987

Bessy, E. (2016). Peningkatan Hasil Belajar Biologi Dengan Materi Pencemaran Lingkungan Melalui Penerapan Metode Pembelajaran Berbasis Tugas Proyek Bagi Peserta didik Kelas X Semester Ii Sma Negeri 5 Kota Ternate Tahun Pelajaran 2015/2016. Edukasi. 14. Https://Doi.Org/10.33387/J.Edu.V14i2.193

Cawi, I. W. (2014). Pengaruh Model Pembelajaran Berbasis Projek Terhadap Hasil Belajar Menggambar Layout Dengan Kovariabel Kecerdasan Spasial Dan Kecerdasan Logis Matematis. 4, 11.

Dimyati, \& Mujdiono. (2002). Belajar Dan Pembelajaran. Rineka Cipta.

Insyasiska, D., Zubaidah, S., \& Susilo, H. (2017). Pengaruh Project Based Learning Terhadap Motivasi Belajar, Kreativitas, Kemampuan Berpikir Kritis, Dan Kemampuan Kognitif Peserta didik Pada Pembelajaran Biologi. 7(1), 13.

Kristanti, Y. D., \& Handayani, R. D. (2016). Pada Pembelajaran Fisika Disma. 5, 7. 
Mahanal, S., Darmawan, E., Corebima, A. D., \& Zubaidah, S. (2010). Pengaruh Pembelajaran Project Based Learning (Pjbl) Pada Materi Ekosistem Terhadap Sikap Dan Hasil Belajar Peserta didik Sman 2 Malang. Bioedukasi (Jurnal Pendidikan Biologi). 1 (1). Https://Doi.Org/10.24127/Bioedukasi.V1i1.179

Maula, M. M., Prihatin, J., Fikri, K., \& Kalimantan, J. (2014). Pengaruh Model Pjbl (Project-Based Learning) Terhadap Kemampuan Berpikir Kreatif Dan Hasil Belajar Peserta didik Pada Materi Pengelolaan Lingkungan. 6.

Mayasari, T., Kadarohman, A., Rusdiana, D., \& Kaniawati, I. (2016). Apakah Model Pembelajaran Problem Based Learning Dan Project Based Learning Mampu Melatihkan Keterampilan Abad 21. Jurnal Pendidikan Fisika Dan Keilmuan (Jpfk). 2(1), 48. Https://Doi.Org/10.25273/Ipfk.V2i1.24

Nawawi, S. (2017). Pengaruh Model Pembelajaran Berbasis Proyek Terhadap Keterampilan Proses Sains Pada Materi Pengelolaan Lingkungan. 4 (2), 9.

Nayono, S. E., \& Er, N. (2013). PENGEMBANGAN MODEL PEMBELAJARAN. 8.

Noviyana, H. (2017). Pengaruh Model Project Based Learning Terhadap Kemampuan Berpikir Kreatif Matematika Peserta didik. Jurnal E-Dumath, 3 (2). Https://Doi.Org/10.26638/Je.455.2064

Nurdyansyah, \& Eny Ff. (2016). Inovasi Model Pembelajaran. Nizamia Learning Center.

Nurohman, S. (2010). Pendekatan Project Based Learning Sebagai Upaya Internalisasi Scientific Method Bagi Mahapeserta Didik Calon Guru Fisika

Rais, M., \& Pd, S. (N.D.). (2010). Project-Based Learning: Inovasi Pembelajaran Yang Berorientasi Soft Skills. 18.

Taniredja, T, Efi M.F, \& Sri H. (2011). Model-model Pembelajaran Inovatif. Alfabeta.

Titu, M. A. (2015). PENERAPAN MODEL PEMBELAJARAN PROJECT BASED LEARNING (PjBL) UNTUK MENINGKATKAN KREATIVITAS PESERTA DIDIK PADA MATERI KONSEP MASALAH EKONOMI. 11.

Thomas, J.W. (2000). A review of research on project based learning. The Autodesk Foundation. 146. Oktober 23, 2018. Tersedia di http://www.bie.org/index.php/site/RE/pbl research/29.

Trisdiono, H. (2013). Strategi Pembelajaran Abad 21. Lembaga Penjaminan Mutu Pendidikan Prov.D.I Yogyakarta.

Utami, R.P, Riezky M.P, \& Umi F. (2015). Pengaruh Model Pembelajran Project Based Learning Berbantu Instagram Terhadap Keterampilan Berpikir Kreatif Peserta Didik Kelas X Sma Negeri 8 Surakarta. 4 (1).

Wena, M. (2009). Strategi Pembelajaran Inovatif Kontemporer. Bumi Aksara. 
Wijayanto, H., \& Utomo, S. B. (2017). Upaya Peningkatan Sikap Ilmiah Dan Prestasi Belajar Peserta didik Melalui Penerapan Project Based Learning (Pjbl) Dilengkapi Media Webquest Pada Pembelajaran Kimia Materi Sistem Koloid Kelas Xi Ipa 2 Sman Gondangrejo Tahun Pelajaran 2015/2016. Jurnal Pendidikan Kimia. 6 (1), 7.

\begin{tabular}{|l|l|}
\hline Fatmah Kamaruddin & $\begin{array}{l}\text { S.Pd. Mahasiswa Jurusan Biologi, Fakultas Matematika dan Ilmu } \\
\text { Pengetahuan Universitas Negeri Makassar } \\
\text { E-mail: fatmahkamaruddin@gmail.com }\end{array}$ \\
\hline Halifah Pagarra & $\begin{array}{l}\text { Ir, M.Si, Ph.D, Prof. Dosen Jurusan Biologi, Fakultas Matematika dan } \\
\text { Ilmu Pengetahuan Universitas Negeri Makassar } \\
\text { E-mail: halifah.pagarra@unm.ac.id }\end{array}$ \\
\hline Nurhayati B & $\begin{array}{l}\text { S.Pd, M.Pd, Dr, Prof. Dosen Jurusan Biologi, Fakultas Matematika dan } \\
\text { Ilmu Pengetahuan Universitas Negeri Makassar } \\
\text { E-mail: } \underline{\text { nurhayati.b@unm.ac.id }}\end{array}$ \\
\hline
\end{tabular}

